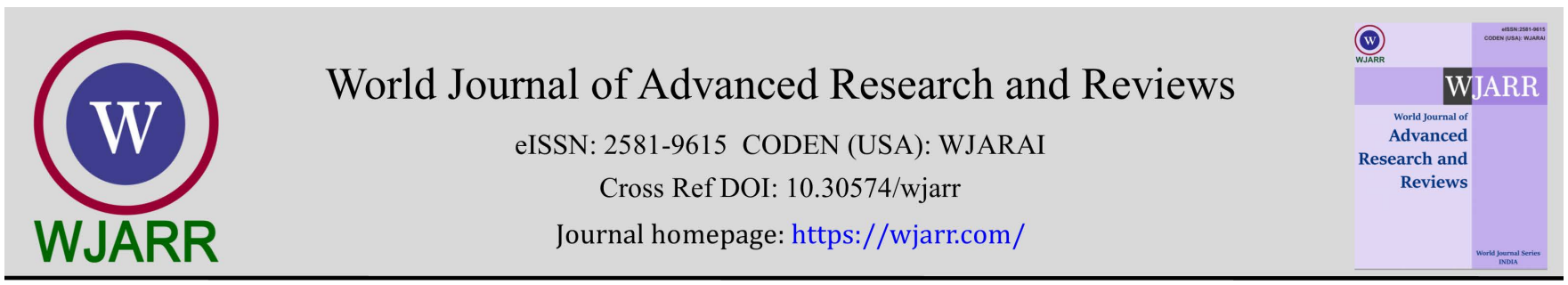

(RESEARCH ARTICLE)

\title{
Evaluation of twenty chemical element contents in thyroid adenomas using neutron activation analysis and inductively coupled plasma atomic emission spectrometry
}

\author{
Vladimir Zaichick* \\ Radionuclide Diagnostics Department Medical Radiological Research Centre Obninsk, Russia.
}

World Journal of Advanced Research and Reviews, 2021, 11(03), 242-257

Publication history: Received on 13 August 2021; revised on 20 September 2021; accepted on 22 September 2021

Article DOI: https://doi.org/10.30574/wjarr.2021.11.3.0448

\begin{abstract}
Thyroid adenomas (TA) are benign tumors, but there is a $20 \%$ possibility of malignant transformation. The distinguishing between the TA and thyroid cancer (TC) is tricky, therefore new TA biomarkers are needed. Furthermore, the role of chemical elements (ChE) in etiology and pathogenesis of TA is unclear. The aim of this exploratory study was to evaluate whether significant changes in the thyroid tissue levels of twenty chemical elements (ChE) $\mathrm{Al}, \mathrm{B}, \mathrm{Ba}, \mathrm{Br}, \mathrm{Ca}$, $\mathrm{Cl}, \mathrm{Cu}, \mathrm{Fe}, \mathrm{I}, \mathrm{K}, \mathrm{Li}, \mathrm{Mg}, \mathrm{Mn}, \mathrm{Na}, \mathrm{P}, \mathrm{S}, \mathrm{Si}, \mathrm{Sr}, \mathrm{V}$, and $\mathrm{Zn}$ exist in the adenomatous transformed thyroid. Thyroid tissue levels of twenty ChE were prospectively evaluated in 19 patients with TA and 105 healthy inhabitants. Measurements were performed using a combination of non-destructive and destructive methods: instrumental neutron activation analysis and inductively coupled plasma atomic emission spectrometry, respectively. Tissue samples were divided into two portions. One was used for morphological study while the other was intended for ChE analysis. It was found that contents of of $\mathrm{Al}, \mathrm{B}, \mathrm{Br}, \mathrm{Cl}, \mathrm{Cu}, \mathrm{Na}$, and $\mathrm{Zn}$ are significantly higher whereas the levels of I some lower. in TA than in normal tissues. It was supposed that the changes in levels $\mathrm{Al}, \mathrm{B}, \mathrm{Br}, \mathrm{Cl}, \mathrm{Cu}, \mathrm{I}, \mathrm{Na}$, and $\mathrm{Zn}$ in thyroid tissue can be used as $\mathrm{TA}$ markers.
\end{abstract}

Keywords: Thyroid adenomas; Intact thyroid; Chemical elements; Biomarkers for adenoma diagnosis; Instrumental neutron activation analysis; Inductively coupled plasma atomic emission spectrometry

\section{Introduction}

Thyroid adenomas (TA) are homogenous, solitary, encapsulated benign tumors, more common in females, and have a good prognosis [1]. However, because there is a $20 \%$ possibility of malignant transformation, TA should be differentiated from other thyroid nodular diseases such as nodular goiter (NG) and thyroid cancer (TC). The distinguishing between the TA and TC is tricky, therefore new differential diagnostics and TA biomarkers are needed $[2,3]$.

For over 20th century, there was the dominant opinion that NG, including TA, is the simple consequence of iodine (I) deficiency. However, it was found that NG is a frequent disease even in those countries and regions where the population is never exposed to I shortage [4]. Moreover, it was shown that I excess has severe consequences on human health and associated with the presence of thyroidal disfunctions and autoimmunity, nodular and diffuse goiters, adenomas and malignant tumors of gland [5-8]. It was also demonstrated that besides the I deficiency and excess many other dietary, environmental, and occupational factors are associated with the NG incidence [9-11]. Among them a disturbance of evolutionary stable input of many (ChE) in human body after industrial revolution plays a significant role in etiology of thyroidal disorders [12].

\footnotetext{
${ }^{*}$ Corresponding author: Vladimir Zaichick

Radionuclide Diagnostics Department Medical Radiological Research Centre Obninsk, Russia. 
Besides I involved in thyroid function, other ChE have also essential physiological functions such as maintenance and regulation of cell function, gene regulation, activation or inhibition of enzymatic reactions, and regulation of membrane function [13]. Essential or toxic (goitrogenic, mutagenic, carcinogenic) properties of ChE depend on tissue-specific need or tolerance, respectively [13]. Excessive accumulation or an imbalance of the ChE may disturb the cell functions and may result in cellular degeneration, death, benign or malignant transformation [13-15].

In our previous studies the complex of in vivo and in vitro nuclear analytical and related methods was developed and used for the investigation of I and other ChE contents in the normal and pathological thyroid [16-22]. Level of I in the normal thyroid was investigated in relation to age, gender and some non-thyroidal diseases [23,24]. After that, variations of ChE content with age in the thyroid of males and females were studied and age- and gender-dependence of some ChE was observed [25-41]. Furthermore, a significant difference between some ChE contents in normal and cancerous thyroid was demonstrated [42-47].

To date, the etiology and pathogenesis of TA has to be considered as multifactorial. The present study was performed to clarify the role of some TE in the TA etiology. Having this in mind, our aim was to assess the aluminum (Al), boron $(\mathrm{B})$, barium $(\mathrm{Ba})$, bromine $(\mathrm{Br})$, calcium $(\mathrm{Ca})$, chlorine $(\mathrm{Cl})$, coper $(\mathrm{Cu})$, iron $(\mathrm{Fe})$, I, potassium $(\mathrm{K})$, lithium $(\mathrm{Li})$, magnesium (Mg), manganese (Mn), sodium (Na), phosphorus $(\mathrm{P})$, sulfur $(\mathrm{S})$, silicon (Si), strontium (Sr), vanadium (V), and zinc $(\mathrm{Zn})$ mass fraction contents in TA tissue using a combination of non-destructive and destructive methods: instrumental neutron activation analysis with high resolution spectrometry of short-lived radionuclides (INAA-SLR) and inductively coupled plasma atomic emission spectrometry (ICPAES), respectively. A further aim was to compare the levels of these twenty ChE in the adenomatous thyroid with those in normal gland of apparently healthy persons.

All studies were approved by the Ethical Committees of the Medical Radiological Research Centre (MRRC), Obninsk. All the procedures performed in studies involving human participants were in accordance with the ethical standards of the institutional and/or national research committee and with the 1964 Helsinki declaration and its later amendments, or with comparable ethical standards.

\section{Material and methods}

All patients suffered from TA $(n=19,16$ females and 3 males, mean age $M \pm S D$ was $41 \pm 11$ years, range 22-55) were hospitalized in the Head and Neck Department of the Medical Radiological Research Centre. Thick-needle puncture biopsy of suspicious nodules of the thyroid was performed for every patient, to permit morphological study of thyroid tissue at these sites and to estimate their TE contents. For all patients the diagnosis has been confirmed by clinical and morphological results obtained during studies of biopsy and resected materials. Histological conclusion for all thyroidal lesions was the TA.

Normal thyroids for the control group samples were removed at necropsy from 105 deceased (mean age $44 \pm 21$ years, range 2-87), who had died suddenly. Samples were obtained within 48 hours after a sudden death. The majority of deaths were due to trauma. A histological examination in the control group was used to control the age norm conformity, as well as to confirm the absence of micro-nodules and latent cancer.

All tissue samples were divided into two portions using a titanium scalpel [48]. One was used for morphological study while the other was intended for ChE analysis. After the samples intended for ChE analysis were weighed, they were freeze-dried and homogenized [49].

The pounded samples weighing about $10 \mathrm{mg}$ (for biopsy) and $100 \mathrm{mg}$ (for resected materials) were used for ChE measurement by INAA-SLR. The content of $\mathrm{Br}, \mathrm{Ca}, \mathrm{Cl}, \mathrm{I}, \mathrm{K}, \mathrm{Mg}, \mathrm{Mn}$, and $\mathrm{Na}$ were determined by INAA-SLR using a horizontal channel equipped with the pneumatic rabbit system of the WWR-c research nuclear reactor (Branch of Karpov Institute, Obninsk). After non-destructive INAA-SLR investigation the thyroid samples were used for ICP-AES. The samples were decomposed in autoclaves. Simultaneously, the same procedure was performed in autoclaves without tissue samples (containing only $\mathrm{HNO}_{3}+\mathrm{H}_{2} \mathrm{O}_{2}+$ deionized water), and the resultant solutions were used as control samples. Sample aliquots were used to determine the $\mathrm{Al}, \mathrm{B}, \mathrm{Ba}, \mathrm{Ca}, \mathrm{Cu}, \mathrm{Fe}, \mathrm{K}, \mathrm{Li}, \mathrm{Mg}, \mathrm{Mn}, \mathrm{Na}, \mathrm{P}, \mathrm{S}, \mathrm{Si}, \mathrm{Sr}, \mathrm{V}$, and Zn mass fractions by ICP-AES using the Spectrometer ICAP-61 (Thermo Jarrell Ash, USA). The determination of the ChE content in aqueous solutions was made by the quantitative method using calibration solutions (High Purity Standards, USA) of 0.5 and $10 \mathrm{mg} / \mathrm{L}$ of each element. The calculations of the ChE content in the probe were carried out using software of a spectrometer (ThermoSPEC, version 4.1). 
Information detailing with the NAA-SLR and ICP-AES methods used and other details of the analysis were presented in our earlier publications concerning ChE contents in human thyroid, scalp hair, and prostate[33,34,50-55].

To determine contents of the ChE by comparison with a known standard, biological synthetic standards (BSS) prepared from phenol-formaldehyde resins were used [56]. In addition to BSS, aliquots of commercial, chemically pure compounds were also used as standards. Ten sub-samples of certified reference material (CRM) IAEA H-4 (animal muscle) and five sub-samples of CRM of the Institute of Nuclear Chemistry and Technology (INCT, Warszawa, Poland) INCT-SBF-4 Soya Bean Flour, INCT-TL-1 Tea Leaves, and INCT-MPH-2 Mixed Polish Herbs were treated and analyzed in the same conditions that thyroid samples to estimate the precision and accuracy of results.

A dedicated computer program for INAA mode optimization was used [57]. All thyroid samples were prepared in duplicate, and mean values of ChE contents were used. Mean values of ChE contents were used in final calculation for the $\mathrm{Br}, \mathrm{Fe}, \mathrm{Rb}$, and $\mathrm{Zn}$ mass fractions measured by two methods. Using Microsoft Office Excel, a summary of the statistics, including, arithmetic mean, standard deviation, standard error of mean, minimum and maximum values, median, percentiles with 0.025 and 0.975 levels was calculated for ChE contents. The difference in the results between two groups (normal thyroid and TA) was evaluated by the parametric Student's $t$-test and non-parametric Wilcoxon-MannWhitney $U$-test.

\section{Results}

Table 1 depicts our data for $\mathrm{Br}, \mathrm{Ca}, \mathrm{Cl}, \mathrm{K}, \mathrm{Mg}, \mathrm{Mn}$, and $\mathrm{Na}$ mass fractions in ten sub-samples of CRM IAEA H-4 (animal muscle) certified reference material and the certified values of this material.

Table 1 INAA-SLR data of chemical element contents in the IAEA H-4 (animal muscle) reference material compared to certified values (mg/kg on dry mass basis)

\begin{tabular}{|c|c|c|c|c|}
\hline \multirow[t]{2}{*}{ Element } & \multicolumn{3}{|c|}{ Certified values } & \multirow{2}{*}{$\begin{array}{c}\text { This work results } \\
\text { Mean } \pm \text { SD }\end{array}$} \\
\hline & Mean & $95 \%$ confidence interval & Type & \\
\hline $\mathrm{Br}$ & 4.1 & $3.5-4.7$ & $\mathrm{C}$ & $5.0 \pm 0.9$ \\
\hline $\mathrm{Ca}$ & 188 & $163-213$ & $\mathrm{C}$ & $238 \pm 59$ \\
\hline $\mathrm{Cl}$ & 1890 & $1810-1970$ & $\mathrm{C}$ & $1950 \pm 230$ \\
\hline K & 15800 & $15300-16400$ & $\mathrm{C}$ & $16200 \pm 3800$ \\
\hline $\mathrm{Mg}$ & 1050 & $990-1110$ & $\mathrm{C}$ & $1100 \pm 190$ \\
\hline $\mathrm{Mn}$ & 0.52 & $0.48-0.55$ & $\mathrm{~N}$ & $0.55 \pm 0.11$ \\
\hline $\mathrm{Na}$ & 2060 & $1930-2180$ & $\mathrm{C}$ & $2190 \pm 140$ \\
\hline
\end{tabular}

Table 2 presents our data for $\mathrm{Al}, \mathrm{B}, \mathrm{Ba}, \mathrm{Ca}, \mathrm{Cu}, \mathrm{Fe}, \mathrm{K}, \mathrm{Li}, \mathrm{Mg}, \mathrm{Mn}, \mathrm{Na}, \mathrm{P}, \mathrm{S}, \mathrm{Si}, \mathrm{Sr}, \mathrm{V}$, and $\mathrm{Zn}$ mass fractions in five sub-samples of INCT-SBF-4 Soya Bean Flour, INCT-TL-1 Tea Leaves and INCT-MPH-2 Mixed Polish Herbs certified reference materials and the certified (or informative) values of this material

The comparison of our results for the $\mathrm{Ca}, \mathrm{K}, \mathrm{Mg}, \mathrm{Mn}$, and Na mass fractions ( $\mathrm{mg} / \mathrm{kg}$, dry mass basis) in the normal human thyroid obtained by both INAA-SLR and ICP-AES methods is shown in Table 3. 
Table 2 ICP-AES data of chemical element contents in Certified Reference Materials (M $\pm \mathrm{SD}, \mathrm{mg} / \mathrm{kg}$ on dry mass basis)

\begin{tabular}{|c|c|c|c|c|c|c|}
\hline \multirow[t]{2}{*}{ Element } & \multicolumn{2}{|c|}{$\begin{array}{l}\text { Soya Bean Flour } \\
\text { (INCT-SBF-4) }\end{array}$} & \multicolumn{2}{|c|}{$\begin{array}{l}\text { Tea Leaves } \\
\text { (INCT-TL-1) }\end{array}$} & \multicolumn{2}{|c|}{$\begin{array}{l}\text { Mixed Polish Herbs } \\
\text { (INCT-MPH-2) }\end{array}$} \\
\hline & Certificate & $\begin{array}{l}\text { This work } \\
\text { result }\end{array}$ & Certificate & $\begin{array}{l}\text { This work } \\
\text { result }\end{array}$ & Certificate & $\begin{array}{l}\text { This work } \\
\text { result }\end{array}$ \\
\hline $\mathrm{Al}$ & $45.5 \pm 3.7$ & $37.1 \pm 1.4$ & $2290 \pm 280$ & $2248 \pm 61$ & $670 \pm 111$ & $485 \pm 79$ \\
\hline B & $39.9 \pm 4.0$ & $34.5 \pm 1.4$ & $26^{\mathrm{a}}$ & $24.8 \pm 1.2$ & - & $28.8 \pm 8.1$ \\
\hline $\mathrm{Ba}$ & $7.30 \pm 0.23$ & $7.38 \pm 0.23$ & $43.2 \pm 3.9$ & $44.7 \pm 2.6$ & $32.5 \pm 2.5$ & $32.2 \pm 0.6$ \\
\hline $\mathrm{Ca}$ & $2467 \pm 170$ & $2737 \pm 190$ & $5820 \pm 520$ & $6296 \pm 360$ & $10800 \pm 700$ & $10250 \pm 294$ \\
\hline $\mathrm{Cu}$ & $14.3 \pm 0.5$ & $14.2 \pm 0.8$ & $20.4 \pm 1.5$ & $19.7 \pm 1.1$ & $7.77 \pm 0.53$ & $8.28 \pm 0.47$ \\
\hline $\mathrm{Fe}$ & $90.8 \pm 4.0$ & $80.5 \pm 6.9$ & $432^{\mathrm{a}}$ & $493 \pm 39$ & $460^{\mathrm{a}}$ & $459 \pm 33$ \\
\hline $\mathrm{K}$ & $24230 \pm 830$ & $25230 \pm 1090$ & $17000 \pm 1200$ & $17810 \pm 1320$ & $19100 \pm 1200$ & $20280 \pm 870$ \\
\hline $\mathrm{Li}$ & - & $0.0047 \pm 0.0018$ & - & $0.217 \pm 0.034$ & - & $0.574 \pm 0.044$ \\
\hline $\mathrm{Mg}$ & $3005 \pm 82$ & $2983 \pm 340$ & $2240 \pm 170$ & $2415 \pm 115$ & $2920 \pm 180$ & $2955 \pm 159$ \\
\hline Mn & $32.3 \pm 1.1$ & $30.0 \pm 1.0$ & $1570 \pm 110$ & $1628 \pm 145$ & $191 \pm 12$ & $197 \pm 5$ \\
\hline $\mathrm{Na}$ & - & $10.2 \pm 3.4$ & $24.7 \pm 3.2$ & $24.2 \pm 3.5$ & $350^{\mathrm{a}}$ & $338 \pm 17$ \\
\hline $\mathrm{P}$ & $6555 \pm 355$ & $6782 \pm 248$ & $1800^{\mathrm{a}}$ & $2457 \pm 150$ & $2500^{\mathrm{a}}$ & $3022 \pm 481$ \\
\hline S & $4245 \pm 471$ & $4468 \pm 529$ & $2470 \pm 250$ & $2500 \pm 230$ & $2410 \pm 140$ & $2409 \pm 159$ \\
\hline $\mathrm{Si}$ & - & $26.7 \pm 4.8$ & - & $325 \pm 34$ & - & $268 \pm 64$ \\
\hline $\mathrm{Sr}$ & $9.32 \pm 0.46$ & $8.76 \pm 0.21$ & $20.8 \pm 1.7$ & $19.8 \pm 1.0$ & $37.6 \pm 2.7$ & $37.4 \pm 2.1$ \\
\hline V & - & $\leq 0.22$ & $2.0 \pm 0.4$ & $1.8 \pm 0.2$ & $0.95 \pm 0.16$ & $0.90 \pm 0.04$ \\
\hline $\mathrm{Zn}$ & $52.3 \pm 1.3$ & $54.8 \pm 6.6$ & $34.7 \pm 2.7$ & $36.0 \pm 3.7$ & $33.5 \pm 2.1$ & $32.0 \pm 6.1$ \\
\hline
\end{tabular}

Table 3 Comparison of the mean values $(\mathrm{M} \pm \mathrm{SEM})$ of the chemical element mass fractions (mg/kg, on dry-mass basis) in the normal human thyroid (males and females combined) obtained by both NAA-SLR and ICP-AES methods

\begin{tabular}{|l|c|c|c|}
\hline Element & NAA-SLR (M) & ICP-AES $\left(\mathbf{M}_{\mathbf{2}}\right)$ & $\boldsymbol{\Delta}, \mathbf{\%}$ \\
\hline $\mathrm{Ca}$ & $1692 \pm 109$ & $1633 \pm 108$ & 3.5 \\
\hline $\mathrm{K}$ & $6071 \pm 306$ & $6764 \pm 298$ & -11.4 \\
\hline $\mathrm{Mg}$ & $285 \pm 17$ & $308 \pm 17$ & -8.1 \\
\hline $\mathrm{Mn}$ & $1.35 \pm 0.07$ & $1.21 \pm 0.07$ & 10.4 \\
\hline $\mathrm{Na}$ & $6702 \pm 178$ & $7154 \pm 201$ & -6.7 \\
\hline
\end{tabular}

Table 4 presents certain statistical parameters (arithmetic mean, standard deviation, standard error of mean, minimal and maximal values, median, percentiles with 0.025 and 0.975 levels) of the $\mathrm{Al}, \mathrm{B}, \mathrm{Ba}, \mathrm{Br}, \mathrm{Ca}, \mathrm{Cl}, \mathrm{Cu}, \mathrm{Fe}, \mathrm{I}, \mathrm{K}, \mathrm{Li}, \mathrm{Mg}, \mathrm{Mn}$, $\mathrm{Na}, \mathrm{P}, \mathrm{S}, \mathrm{Si}, \mathrm{Sr}, \mathrm{V}$, and Zn mass fraction in normal and adenomatous thyroid. 
Table 4 Some statistical parameters of $\mathrm{Al}, \mathrm{B}, \mathrm{Ba}, \mathrm{Br}, \mathrm{Ca}, \mathrm{Cl}, \mathrm{Cu}, \mathrm{Fe}, \mathrm{I}, \mathrm{K}, \mathrm{Li}, \mathrm{Mg}, \mathrm{Mn}, \mathrm{Na}, \mathrm{P}, \mathrm{S}, \mathrm{Si}, \mathrm{Sr}$, V, and Zn mass fraction $(\mathrm{mg} / \mathrm{kg}$, dry mass basis) in normal and adenomatous thyroid

\begin{tabular}{|c|c|c|c|c|c|c|c|c|c|}
\hline Tissue & Element & Mean & SD & SEM & Min & Max & Median & P 0.025 & P 0.975 \\
\hline Normal & $\mathrm{Al}$ & 10.5 & 13.4 & 1.8 & 0.800 & 69.3 & 6.35 & 1.19 & 52.9 \\
\hline \multirow[t]{19}{*}{$n=105$} & $\mathrm{~B}$ & 0.476 & 0.434 & 0.058 & 0.200 & 2.30 & 0.300 & 0.200 & 1.73 \\
\hline & $\mathrm{Ba}$ & 1.12 & 1.15 & 0.15 & 0.0480 & 5.00 & 0.680 & 0.0838 & 4.48 \\
\hline & $\mathrm{Br}$ & 14.9 & 11.0 & 1.2 & 1.90 & 54.1 & 11.6 & 2.56 & 49.3 \\
\hline & $\mathrm{Ca}$ & 1682 & 999 & 106 & 373 & 5582 & 1454 & 444 & 4183 \\
\hline & $\mathrm{Cl}$ & 3400 & 1452 & 174 & 1030 & 6000 & 3470 & 1244 & 5869 \\
\hline & $\mathrm{Cu}$ & 4.08 & 1.22 & 0.14 & 0.500 & 7.15 & 4.10 & 1.57 & 6.41 \\
\hline & $\mathrm{Fe}$ & 223 & 95 & 10 & 52.0 & 489 & 210 & 72.8 & 432 \\
\hline & I & 1841 & 1027 & 107 & 114 & 5061 & 1695 & 230 & 4232 \\
\hline & $\mathrm{K}$ & 6418 & 2625 & 290 & 1914 & 15293 & 5948 & 2947 & 13285 \\
\hline & $\mathrm{Li}$ & 0.0208 & 0.0155 & 0.0022 & 0.0015 & 0.0977 & 0.0178 & 0.0041 & 0.0487 \\
\hline & $\mathrm{Mg}$ & 296 & 134 & 16 & 66.0 & 930 & 284 & 95.8 & 541 \\
\hline & $\mathrm{Mn}$ & 1.28 & 0.56 & 0.07 & 0.470 & 4.04 & 1.15 & 0.537 & 2.23 \\
\hline & $\mathrm{Na}$ & 6928 & 1730 & 175 & 3686 & 13453 & 6835 & 3974 & 10709 \\
\hline & $\mathrm{P}$ & 4290 & 1578 & 207 & 496 & 8996 & 4221 & 1360 & 7323 \\
\hline & $\mathrm{S}$ & 8259 & 2002 & 263 & 644 & 11377 & 8399 & 3662 & 11208 \\
\hline & $\mathrm{Si}$ & 50.8 & 46.9 & 6.2 & 5.70 & 180 & 36.0 & 7.11 & 174 \\
\hline & $\mathrm{Sr}$ & 3.81 & 2.93 & 0.34 & 0.100 & 12.6 & 2.90 & 0.365 & 11.3 \\
\hline & $\mathrm{V}$ & 0.102 & 0.039 & 0.005 & 0.0200 & 0.250 & 0.100 & 0.0440 & 0.192 \\
\hline & $\mathrm{Zn}$ & 94.8 & 39.6 & 4.2 & 7.10 & 215 & 88.5 & 34.9 & 196 \\
\hline Adenoma & $\mathrm{Al}$ & 34.3 & 24.1 & 9.1 & 8.70 & 78.4 & 30.6 & 9.53 & 74.1 \\
\hline \multirow[t]{19}{*}{$\mathrm{n}=19$} & $\mathrm{~B}$ & 3.38 & 2.74 & 1.12 & 1.00 & 7.30 & 3.00 & 1.00 & 7.01 \\
\hline & $\mathrm{Ba}$ & 3.06 & 4.07 & 1.54 & 0.410 & 11.7 & 1.40 & 0.454 & 10.7 \\
\hline & $\mathrm{Br}$ & 394 & 397 & 125 & 11.6 & 1080 & 203 & 22.5 & 1033 \\
\hline & $\mathrm{Ca}$ & 1370 & 1030 & 311 & 52.0 & 3582 & 1252 & 136 & 3353 \\
\hline & $\mathrm{Cl}$ & 7722 & 3785 & 1262 & 1757 & 13824 & 9085 & 2043 & 113179 \\
\hline & $\mathrm{Cu}$ & 17.6 & 14.0 & 5.7 & 4.10 & 35.2 & 13.8 & 4.28 & 35.0 \\
\hline & $\mathrm{Fe}$ & 429 & 405 & 108 & 52.3 & 1360 & 335 & 53.3 & 1326 \\
\hline & I & 962 & 1013 & 232 & 131 & 3906 & 476 & 170 & 3591 \\
\hline & $\mathrm{K}$ & 5603 & 2727 & 756 & 797 & 10099 & 5741 & 937 & 9600 \\
\hline & $\mathrm{Li}$ & 0.0401 & .0 .0236 & 0.0100 & 0.0185 & 0.0680 & 0.0341 & 0.0186 & 0.0678 \\
\hline & $\mathrm{Mg}$ & 236 & 108 & 30 & 15.0 & 397 & 269 & 36.9 & 376 \\
\hline & $\mathrm{Mn}$ & 1.67 & 1.88 & 0.54 & 0.100 & 6.12 & 0.805 & 0.210 & 5.50 \\
\hline & $\mathrm{Na}$ & 9747 & 4746 & 1316 & 2319 & 18734 & 9100 & 2728 & 18038 \\
\hline & $\mathrm{P}$ & 4930 & 1945 & 735 & 2982 & 8932 & 4300 & 3072 & 8395 \\
\hline & $\mathrm{S}$ & 10536 & 2968 & 1122 & 7865 & 16706 & 9486 & 8017 & 15970 \\
\hline & $\mathrm{Si}$ & 114 & 106 & 40 & 15.2 & 346 & 83.7 & 24.6 & 310 \\
\hline & $\mathrm{Sr}$ & 3.30 & 2.18 & 0.63 & 0.420 & 6.70 & 2.85 & 0.582 & 6.69 \\
\hline & $\mathrm{V}$ & 0.140 & 0.041 & 0.020 & 0.110 & 0.200 & 0.125 & 0.111 & 0.195 \\
\hline & $\mathrm{Zn}$ & 129 & 50 & 13 & 57.7 & 251 & 137 & 61.3 & 225 \\
\hline
\end{tabular}


Table 5 Median, minimum and maximum value of means $\mathrm{Al}, \mathrm{B}, \mathrm{Ba}, \mathrm{Br}, \mathrm{Ca}, \mathrm{Cl}, \mathrm{Cu}, \mathrm{Fe}, \mathrm{I}, \mathrm{K}, \mathrm{Li}, \mathrm{Mg}, \mathrm{Mn}, \mathrm{Na}, \mathrm{P}, \mathrm{S}, \mathrm{Si}, \mathrm{Sr}, \mathrm{V}$, and $\mathrm{Zn}$ contents in the normal and adenomatous thyroid according to data from the literature in comparison with our results (mg/kg, dry mass basis)

\begin{tabular}{|c|c|c|c|c|}
\hline \multirow{2}{*}{$\begin{array}{c}\text { Tissue } \\
\text { Element }\end{array}$} & \multicolumn{3}{|c|}{ Published data [Reference] } & \multirow{2}{*}{$\begin{array}{c}\text { This work } \\
\text { Males and } \\
\text { females } \\
\mathrm{M} \pm \mathrm{SD}\end{array}$} \\
\hline & $\begin{array}{l}\text { Median of } \\
\text { means } \\
(n)^{*}\end{array}$ & $\begin{array}{c}\text { Minimum of } \\
\text { means } \\
\text { M or } M \pm S D,(n)^{* *}\end{array}$ & $\begin{array}{c}\text { Maximum of } \\
\text { means } \\
\text { M or } M \pm S D,(n)^{* *}\end{array}$ & \\
\hline \multicolumn{5}{|l|}{ Norm } \\
\hline $\mathrm{Al}$ & $33.6(12)$ & $0.33(-)[58]$ & $420(25)[59]$ & $10.5 \pm 13.4$ \\
\hline B & $0.151(2)$ & $0.084(3)[60]$ & $0.46(3)[60]$ & $0.476 \pm 0.434$ \\
\hline $\mathrm{Ba}$ & $0.67(7)$ & $0.0084(83)[61]$ & $\leq 5.0(16)[62]$ & $1.12 \pm 1.15$ \\
\hline $\mathrm{Br}$ & $18.1(11)$ & $5.12(44)[63]$ & $284 \pm 44(14)[64]$ & $16.3 \pm 11.6$ \\
\hline $\mathrm{Ca}$ & $1600(17)$ & $840 \pm 240(10)[65]$ & $3800 \pm 320(29)[65]$ & $1663 \pm 999$ \\
\hline $\mathrm{Cl}$ & $6800(5)$ & $804 \pm 80(4)[66]$ & $8000(-)[67]$ & $3400 \pm 1452$ \\
\hline $\mathrm{Cu}$ & $6.0(61)$ & $0.16(83)[61]$ & $220 \pm 22(10)[66]$ & $3.93 \pm 1.43$ \\
\hline $\mathrm{Fe}$ & $252(21)$ & $56(120)[68]$ & $3360(25)[59]$ & $223 \pm 95$ \\
\hline I & $1888(95)$ & $159 \pm 8(23)[69]$ & $5772 \pm 2708(50)[70]$ & $1841 \pm 1027$ \\
\hline K & $4300(17)$ & $46.4 \pm 4.8(4)[66]$ & $6090(17)[62]$ & $6418 \pm 2625$ \\
\hline $\mathrm{Li}$ & $6.3(2)$ & $0.092(-)[71]$ & $12.6(180)[72]$ & $0.0208 \pm 0.0154$ \\
\hline Mg & $390(16)$ & $3.5(-)[58]$ & $1520(20)[73]$ & $296 \pm 134$ \\
\hline $\mathrm{Mn}$ & $1.62(40)$ & $0.076(83)[61]$ & $69.2 \pm 7.2(4)[66]$ & $1.28 \pm 0.56$ \\
\hline $\mathrm{Na}$ & $8000(9)$ & $438(-)[74]$ & $10000 \pm 5000(11)$ [75] & $6928 \pm 1730$ \\
\hline $\mathrm{P}$ & $2860(10)$ & $16(7)[76]$ & $7520(60)[63]$ & $4290 \pm 1578$ \\
\hline S & $11000(3)$ & $4000(-)[67]$ & 11800 (44) [63] & $8259 \pm 2002$ \\
\hline $\mathrm{Si}$ & $16.0(3)$ & $0.97(-)[58]$ & $143 \pm 6(40)[77]$ & $50.8 \pm 46.9$ \\
\hline $\mathrm{Sr}$ & $0.61(9)$ & $0.055(83)[61]$ & $46.8 \pm 4.8(4)[66]$ & $3.81 \pm 2.93$ \\
\hline V & $0.065(6)$ & $0.0124(2)[78]$ & $18 \pm 2(4)[66]$ & $0.102 \pm 0.039$ \\
\hline $\mathrm{Zn}$ & $110(56)$ & $2.1(-)[58]$ & $820 \pm 204(14)[64]$ & $94.8 \pm 39.7$ \\
\hline \multicolumn{5}{|l|}{ Adenoma } \\
\hline $\mathrm{Al}$ & - & - & - & $34.3 \pm 24.1$ \\
\hline B & - & - & - & $3.38 \pm 2.74$ \\
\hline $\mathrm{Ba}$ & - & - & - & $3.06 \pm 4.07$ \\
\hline $\mathrm{Br}$ & $38(4)$ & $11(5)[79]$ & 777 (1) [80] & $394 \pm 397$ \\
\hline $\mathrm{Ca}$ & $2298(4)$ & 900 (1) [65] & 3500 (1) [65] & $1370 \pm 1030$ \\
\hline $\mathrm{Cl}$ & $864(1)$ & $864 \pm 84(4)[66]$ & $864 \pm 84(4)[66]$ & $7722 \pm 3785$ \\
\hline $\mathrm{Cu}$ & $11.0(7)$ & $1.24(46)[81]$ & $29(5)$ [79] & $17.6 \pm 14.0$ \\
\hline $\mathrm{Fe}$ & $92.5(4)$ & $15(5)$ [79] & $2100 \pm 208(4)[66]$ & $429 \pm 405$ \\
\hline I & $640(13)$ & 80 (1) [79] & 2800 (1) [82] & $962 \pm 1013$ \\
\hline
\end{tabular}




\begin{tabular}{|l|c|c|c|c|}
\hline $\mathrm{K}$ & $3650(3)$ & $72,8 \pm 7,2(4)[66]$ & $5600(1)[79]$ & $5603 \pm 2727$ \\
\hline $\mathrm{Li}$ & - & - & - & $0.0401 \pm .0 .0236$ \\
\hline $\mathrm{Mg}$ & - & - & - & $236 \pm 108$ \\
\hline $\mathrm{Mn}$ & $1.28(4)$ & $0.40(46)[81]$ & $57,6 \pm 6,0(4)[66]$ & $1.67 \pm 1.88$ \\
\hline $\mathrm{Na}$ & - & - & - & $9747 \pm 4746$ \\
\hline $\mathrm{P}$ & - & - & - & $4930 \pm 1945$ \\
\hline $\mathrm{S}$ & - & - & - & $10536 \pm 2968$ \\
\hline $\mathrm{Si}$ & - & - & - & $114 \pm 106$ \\
\hline $\mathrm{Sr}$ & $27.2(1)$ & $27.2 \pm 2.4(4)[66]$ & $27.2 \pm 2.4(4)[66]$ & $3.30 \pm 2.18$ \\
\hline $\mathrm{V}$ & $16.8(1)$ & $16.8 \pm 1.6(4)[66]$ & $16.8 \pm 1.6(4)[66]$ & $0.140 \pm 0.041$ \\
\hline $\mathrm{Zn}$ & $68.5(8)$ & $21.0(130)[83]$ & $330 \pm 282(9)[84]$ & $129 \pm 50$ \\
\hline
\end{tabular}

The comparison of our results with published data for $\mathrm{Al}, \mathrm{B}, \mathrm{Ba}, \mathrm{Br}, \mathrm{Ca}, \mathrm{Cl}, \mathrm{Cu}, \mathrm{Fe}, \mathrm{I}, \mathrm{K}, \mathrm{Li}, \mathrm{Mg}, \mathrm{Mn}, \mathrm{Na}, \mathrm{P}, \mathrm{S}, \mathrm{Si}, \mathrm{Sr}, \mathrm{V}$, and $\mathrm{Zn}$ mass fraction in normal and adenomatous thyroid [58-84] is shown in Table 5.

The ratios of means and the difference between mean values of $\mathrm{Al}, \mathrm{B}, \mathrm{Ba}, \mathrm{Br}, \mathrm{Ca}, \mathrm{Cl}, \mathrm{Cu}, \mathrm{Fe}, \mathrm{I}, \mathrm{K}, \mathrm{Li}, \mathrm{Mg}, \mathrm{Mn}, \mathrm{Na}, \mathrm{P}, \mathrm{S}, \mathrm{Si}, \mathrm{Sr}$, $\mathrm{V}$, and $\mathrm{Zn}$ mass fractions in normal and adenomatous thyroid are presented in Table 6.

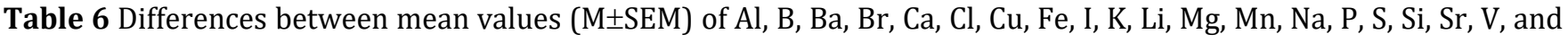
Zn mass fraction ( $\mathrm{mg} / \mathrm{kg}$, dry mass basis) in normal and adenomatous thyroid

\begin{tabular}{|l|c|c|c|c|c|}
\hline \multirow{2}{*}{ Element } & \multicolumn{4}{|c|}{ Thyroid tissue } & Ratio \\
\cline { 2 - 6 } & $\begin{array}{c}\text { Norm } \\
\mathbf{n = 1 0 5}\end{array}$ & $\begin{array}{c}\text { Adenoma } \\
\mathbf{n = 1 9}\end{array}$ & $\begin{array}{c}\text { Student's t-test } \\
\boldsymbol{p} \leq\end{array}$ & $\begin{array}{c}\text { U-test } \\
\boldsymbol{p}\end{array}$ & $\begin{array}{c}\text { Adenoma } \\
\text { to Norm }\end{array}$ \\
\hline $\mathrm{Al}$ & $10.5 \pm 1.8$ & $34.3 \pm 9.1$ & $\mathbf{0 . 0 4 0}$ & $\mathbf{\leq 0 . 0 1}$ & 3.27 \\
\hline $\mathrm{B}$ & $0.476 \pm 0.058$ & $3.38 \pm 1.12$ & $\mathbf{0 . 0 4 8}$ & $\leq \mathbf{0 . 0 1}$ & 7.10 \\
\hline $\mathrm{Ba}$ & $1.12 \pm 0.15$ & $3.06 \pm 1.54$ & 0.256 & $>0.05$ & 2.73 \\
\hline $\mathrm{Br}$ & $14.9 \pm 1.2$ & $394 \pm 125$ & $\mathbf{0 . 0 1 4}$ & $\mathbf{5 0 . 0 1}$ & 26.4 \\
\hline $\mathrm{Ca}$ & $1682 \pm 106$ & $1370 \pm 311$ & 0.360 & $>0.05$ & 0.81 \\
\hline $\mathrm{Cl}$ & $3400 \pm 174$ & $7722 \pm 1262$ & $\mathbf{0 . 0 0 8 9}$ & $\leq \mathbf{0 . 0 1}$ & 2.27 \\
\hline $\mathrm{Cu}$ & $4.08 \pm 0.14$ & $17.6 \pm 5.7$ & 0.064 & $\leq \mathbf{0 . 0 5}$ & 4.31 \\
\hline $\mathrm{Fe}$ & $223 \pm 10$ & $429 \pm 108$ & 0.081 & $>0.05$ & 1.92 \\
\hline $\mathrm{I}$ & $1841 \pm 107$ & $962 \pm 232$ & $\mathbf{0 . 0 0 2 0}$ & $\leq \mathbf{0 . 0 1}$ & 0.52 \\
\hline $\mathrm{K}$ & $6418 \pm 290$ & $5603 \pm 756$ & 0.330 & $>0.05$ & 0.87 \\
\hline $\mathrm{Li}$ & $0.0208 \pm 0.0022$ & $0.0401 \pm 0.0100$ & 0.103 & $>0.05$ & 1.93 \\
\hline $\mathrm{Mg}$ & $296 \pm 16$ & $236 \pm 30$ & 0.088 & $>0.05$ & 0.80 \\
\hline $\mathrm{Mn}$ & $1.28 \pm 0.07$ & $1.67 \pm 0.54$ & 0.488 & $>0.05$ & 1.30 \\
\hline $\mathrm{Na}$ & $6928 \pm 175$ & $9747 \pm 1316$ & 0.054 & $\leq \mathbf{0 . 0 5}$ & 1.41 \\
\hline $\mathrm{P}$ & $4290 \pm 207$ & $4930 \pm 735$ & 0.430 & $>0.05$ & 1.15 \\
\hline $\mathrm{S}$ & $8259 \pm 263$ & $10536 \pm 1122$ & 0.091 & $>0.05$ & 1.28 \\
\hline $\mathrm{Si}$ & $50.8 \pm 6.2$ & $114 \pm 40$ & 0.165 & $>0.05$ & 2.24 \\
\hline $\mathrm{Sr}$ & $3.81 \pm 0.34$ & $3.30 \pm 0.63$ & 0.482 & $>0.05$ & 0.87 \\
\hline $\mathrm{V}$ & $0.102 \pm 0.005$ & $0.140 \pm 0.020$ & 0.159 & $>0.05$ & 1.37 \\
\hline $\mathrm{Zn}$ & $94.8 \pm 4.2$ & $129 \pm 13$ & $\mathbf{0 . 0 2 3}$ & $\leq \mathbf{0 . 0 1}$ & 1.36 \\
\hline
\end{tabular}




\section{Discussion}

\subsection{Precision and accuracy of results}

A good agreement of our results for the $\mathrm{Al}, \mathrm{B}, \mathrm{Ba}, \mathrm{Br}, \mathrm{Ca}, \mathrm{Cl}, \mathrm{Cu}, \mathrm{Fe}, \mathrm{I}, \mathrm{K}, \mathrm{Mg}, \mathrm{Mn}, \mathrm{Na}, \mathrm{P}, \mathrm{S}, \mathrm{Sr}, \mathrm{V}$, and $\mathrm{Zn}$ mass fractions with the certified values of CRM IAEA H-4, INCT-SBF-4, INCT-TL-1, and INCT-MPH-2 (Tables 1 and 2) as well as the similarity of the means of the $\mathrm{Ca}, \mathrm{K}, \mathrm{Mg}, \mathrm{Mn}$, and $\mathrm{Na}$ mass fractions in the normal human thyroid determined by both INAA-SLR and ICP-AES methods (Table 3) demonstrates an acceptable precision and accuracy of the results obtained in the study and presented in Tables 4-6.

The mean values and all selected statistical parameters were calculated for twenty $\mathrm{ChE}(\mathrm{Al}, \mathrm{B}, \mathrm{Ba}, \mathrm{Br}, \mathrm{Ca}, \mathrm{Cl}, \mathrm{Cu}, \mathrm{Fe}, \mathrm{I}, \mathrm{K}$, $\mathrm{Li}, \mathrm{Mg}, \mathrm{Mn}, \mathrm{Na}, \mathrm{P}, \mathrm{S}, \mathrm{Si}, \mathrm{Sr}, \mathrm{V}$, and $\mathrm{Zn}$ ) mass fractions (Table 4). The mass fraction of $\mathrm{Al}, \mathrm{B}, \mathrm{Ba}, \mathrm{Br}, \mathrm{Ca}, \mathrm{Cl}, \mathrm{Cu}, \mathrm{Fe}, \mathrm{I}, \mathrm{K}, \mathrm{Li}, \mathrm{Mg}$, $\mathrm{Mn}, \mathrm{Na}, \mathrm{P}, \mathrm{S}, \mathrm{Si}, \mathrm{Sr}, \mathrm{V}$, and Zn were measured in all, or a major portion of normal and adenomatous thyroid samples.

\subsection{Comparison with published data}

The means obtained for $\mathrm{Al}, \mathrm{B}, \mathrm{Ba}, \mathrm{Br}, \mathrm{Ca}, \mathrm{Cl}, \mathrm{Cu}, \mathrm{Fe}, \mathrm{I}, \mathrm{K}, \mathrm{Mg}, \mathrm{Mn}, \mathrm{Na}, \mathrm{P}, \mathrm{S}, \mathrm{Si}, \mathrm{Sr}, \mathrm{V}$, and $\mathrm{Zn}$ mass fraction, as shown in Table 5 , agree well with the medians of mean values reported by other researches for the human thyroid, including samples received from persons who died from different non-thyroid diseases. The mean obtained for Li is two orders of magnitude lower than the median of previously reported data. Moreover, it is outside the range of previously reported means. A number of values for ChE mass fractions were not expressed on a dry mass basis by the authors of the cited references. Hence we calculated these values using published data for water $75 \%$ [85] and ash $4.16 \%$ on dry mass basis [86] contents in thyroid of adults.

In adenomatous tissues our results for $\mathrm{Br}, \mathrm{Ca}, \mathrm{Cu}, \mathrm{Fe}, \mathrm{I}, \mathrm{Mn}$, and $\mathrm{Zn}$ contents were within the range of published means, while mean for $\mathrm{K}$ was some higher the upper level of the previously reported range of means (Table 5). Only one published article on $\mathrm{Cl}, \mathrm{Sr}$, and $\mathrm{V}$ contents in the adenomatous thyroid samples was found in the literature [66]. The mean obtained in the present study for $\mathrm{Sr}$ and $\mathrm{V}$ content in the adenomatous thyroid were approximately one and two order of magnitude, respectively, lower, whereas for $\mathrm{Cl}$ was one order of magnitude higher than published results . No published data referring $\mathrm{Al}, \mathrm{B}, \mathrm{Ba}, \mathrm{Li}, \mathrm{Mg}, \mathrm{Na}, \mathrm{P}, \mathrm{S}$, and Si contents of adenomatous thyroid were found.

The range of means of $\mathrm{Al}, \mathrm{B}, \mathrm{Ba}, \mathrm{Br}, \mathrm{Ca}, \mathrm{Cl}, \mathrm{Cu}, \mathrm{Fe}, \mathrm{I}, \mathrm{K}, \mathrm{Li}, \mathrm{Mg}, \mathrm{Mn}, \mathrm{Na}, \mathrm{P}, \mathrm{S}, \mathrm{Si}, \mathrm{Sr}, \mathrm{V}$, and $\mathrm{Zn}$ level reported in the literature for normal and for adenomatous thyroid vary widely (Table 5). This can be explained by a dependence of ChE content on many factors, including "normality" of thyroid samples (see above), the region of the thyroid, from which the sample was taken, age, gender, ethnicity, mass of the gland, and the adenoma stage, histology and functional activity. Not all these factors were strictly controlled in cited studies. Another and, in our opinion, leading cause of inter-observer variability can be attributed to the accuracy of the analytical techniques, sample preparation methods, and inability of taking uniform samples from the affected tissues. It was insufficient quality control of results in these studies. In many reported papers tissue samples were ashed or dried at high temperature for many hours. In other cases, thyroid samples were treated with solvents (distilled water, ethanol, formalin etc). There is evidence that by use of these sample preparation methods some quantities of certain $\mathrm{ChE}$ are lost as a result of this treatment That concern not only such volatile halogen as $\mathrm{Br}$, but also other $\mathrm{ChE}$ investigated in the study $[87,88]$.

\subsection{Effect of adenomatous transformation on ChE contents}

From Table 6, it is observed that in $\mathrm{TA}$ the mass fraction of $\mathrm{Al}, \mathrm{B}, \mathrm{Br}, \mathrm{Cl}, \mathrm{Cu}, \mathrm{Na}$ and $\mathrm{Zn}$ are approximately 3.3, 7.1, 26.4, $2.3,4.3,1.41$, and 1.4 times, respectively, higher than in normal tissues of the thyroid. In contrast, the mass fraction of I is $48 \%$ lower. Thus, if we accept the ChE contents in thyroid glands in the control group as a norm, we have to conclude that with a adenomatous transformation the levels of $\mathrm{Al}, \mathrm{B}, \mathrm{Br}, \mathrm{Cl}, \mathrm{Cu}, \mathrm{Na}$, and $\mathrm{Zn}$ in thyroid tissue significantly increased, whereas the level of I decreased.

\subsection{Role of ChE in adenomatous transformation of the thyroid}

Characteristically, elevated or reduced levels of ChE observed in adenomatous thyroid are discussed in terms of their potential role in the initiation and promotion of TA. In other words, using the low or high levels of the ChE in adenomatous thyroid researchers try to determine the role of the deficiency or excess of each ChE in the TA etiology. In our opinion, abnormal levels of many $\mathrm{ChE}$ in TA could be and cause, and also effect of adenomatous transformation. From the results of such kind studies, it is not always possible to decide whether the measured decrease or increase in ChE level in pathologically altered tissue is the reason for alterations or vice versa. 


\subsubsection{Aluminum}

The trace element $\mathrm{Al}$ is not described as essential, because no biochemical function has been directly connected to it. At this stage of our knowledge, there is no doubt that Al overload impacts negatively on human health, including the thyroid function [89].

\subsubsection{Boron}

Trace element B is known to influence the activity of many enzymes [90]. Numerous studies have demonstrated beneficial effects of B on human health, including anti-inflammatory stimulus - reduces levels of inflammatory biomarkers, such as high-sensitivity C-reactive protein (hs-CRP) and tumor necrosis factor $\alpha$ (TNF- $\alpha$ ); as well as raises levels of antioxidant enzymes, such as superoxide dismutase (SOD), catalase, and glutathione peroxidase [91]. Why B content in adenomatous thyroid is higher than normal level and how an excess of B acts on thyroid are still to be cleared.

\subsubsection{Bromine}

This is one of the most abundant and ubiquitous of the recognized trace elements in the biosphere. Inorganic bromide is the ionic form of $\mathrm{Br}$ which exerts therapeutic as well as toxic effects. An enhanced intake of bromide could interfere with the metabolism of I at the whole-body level. In the thyroid gland the biological behavior of bromide is more similar to the biological behavior of iodide [92].

In our previous studies, we found a significant age-related increase of Br content in human thyroid [27,28,31-34]. Therefore, a goitrogenic and tumorogenic effect of excessive Br levels in the thyroid of old females was assumed. On the one hand, elevated levels of $\mathrm{Br}$ in TA, observed in the present study, supports this conclusion. But, on the other hand, bromide compounds, especially potassium bromide (KBr), sodium bromide ( $\mathrm{NaBr}$ ), and ammonium bromide $\left(\mathrm{NH}_{4} \mathrm{Br}\right.$ ), are frequently used as sedatives in Russia [93]. It may be the reason for elevated levels of $\mathrm{Br}$ in specimens of patients with TA.

\subsubsection{Chlorine}

$\mathrm{Cl}$ is a ubiquitous, extracellular electrolyte essential to more than one metabolic pathway. $\mathrm{Cl}$ exists in the ionic form (chloride) in the human body. In the body, it is mostly present as sodium chloride. Therefore, as usual, there is a correlation between $\mathrm{Na}$ and $\mathrm{Cl}$ contents in tissues and fluids of human body. It is well known that $\mathrm{Cl}$ mass fractions in samples depend mainly on the extracellular water volume, including the blood volumes, in tissues [94]. TA tissues are predominantly highly vascularized lesions [95]. Thus, it is possible to speculate that TA are characterized by an increase of the mean value of the $\mathrm{Cl}$ mass fraction because the level of adenoma vascularization is higher than that in normal thyroid tissue.

\subsubsection{Coper}

$\mathrm{Cu}$ is a ubiquitous element in the human body which plays many roles at different levels. Various Cu-enzymes (such as amine oxidase, ceruloplasmin, cytochrome-c oxidase, dopamine-monooxygenase, extracellular superoxide dismutase, lysyl oxidase, peptidylglycineamidating monoxygenase, $\mathrm{Cu} / \mathrm{Zn}$ superoxide dismutase, and tyrosinase) mediate the effects of $\mathrm{Cu}$ deficiency or excess. $\mathrm{Cu}$ excess can have severe negative impacts. Cu generates oxygen radicals and many investigators have hypothesized that excess copper might cause cellular injury via an oxidative pathway, giving rise to enhanced lipid peroxidation, thiol oxidation, and, ultimately, DNA damage [96]. Thus, $\mathrm{Cu}$ accumulation in thyroid parenchyma with age may be involved in oxidative stress, dwindling gland function, and increasing risk of goiter, adenoma, or cancer [25,26,31,33,34]. The significantly elevated level of $\mathrm{Cu}$ in adenomatous thyroid, observed in the present study, supports this speculation. However, an overall comprehension of $\mathrm{Cu}$ homeostasis and physiology, which is not yet acquired, is mandatory to establish $\mathrm{Cu}$ exact role in the TA etiology and metabolism.

\subsubsection{Iodine}

Compared to other soft tissues, the human thyroid gland has higher levels of I, because this element plays an important role in its normal functions, through the production of thyroid hormones (thyroxin and triiodothyronine) which are essential for cellular oxidation, growth, reproduction, and the activity of the central and autonomic nervous system. Adenomatous transformation is accompanied by a partial loss of tissue-specific functional features, which leads to a significant reduction in I content associated with functional characteristics of the human thyroid tissue. 


\subsubsection{Sodium}

Knowledge concerning ion regulation in many normal and abnormal cell processes has had a rapid development. It was found, among other regulations, that sodium-calcium exchange is associated with the cytoskeleton and the cell membrane. A hypothesis was eventually established that a wide variety of pathological phenomena ranging from acute cell death to chronic processes, such as neoplasia, all have a common series of cellular reactions [97]. Furthermore, iodide $\left(\mathrm{I}^{-}\right)$, an essential constituent of the thyroid hormones, is actively transported into the thyroid via the $\mathrm{Na}^{+} / \mathrm{I}^{-}$symporter (NIS), a key plasma membrane glycoprotein [98]. In addition, $\mathrm{Na}$ is mainly an extracellular electrolyte and its elevated level in TA might link with a higher adenoma vascularization in comparison with the normal thyroid (see Chlorine).

\subsubsection{Zinc}

$\mathrm{Zn}$ is active in more than 300 proteins and over 100 DNA-binding proteins, including the tumor suppressor protein p53, a Zn-binding transcription factor acting as a key regulator of cell growth and survival upon various forms of cellular stress. p53 is mutated in half of human tumors and its activity is tightly regulated by metals and redox mechanisms. On the other hand, excessive intracellular Zn concentrations may be harmful to normal metabolism of cells [99]. By now much data has been obtained related both to the direct and indirect action of intracellular Zn on the DNA polymeric organization, replication and lesions, and to its vital role for cell division [100,101]. Other actions of Zn have been also described. They include its action as a potent anti-apoptotic agent [102-106]. All these facts allowed us to speculate that age-related overload $\mathrm{Zn}$ content in female thyroid, as was found in our previous study $[25,29,31,33]$, is probably one of the factors in etiology of thyroid goiter, TA, and malignant tumors. Therefore, the elevated Zn level in TA in comparison with normal level, detected in this study, supports our hypothesis.

Our findings show that mass fraction of $\mathrm{Al}, \mathrm{B}, \mathrm{Br}, \mathrm{Cl}, \mathrm{Cu}, \mathrm{I}, \mathrm{Na}$, and $\mathrm{Zn}$ are significantly different in $\mathrm{TA}$ as compared to normal thyroid tissues (Tables 6). Thus, it is plausible to assume that levels of these $\mathrm{ChE}$ in thyroid tissue can be used as TA markers. However, this subjects needs in additional studies.

\section{Limitations}

This study has several limitations. Firstly, analytical techniques employed in this study measure only twenty ChE (Al, B, $\mathrm{Ba}, \mathrm{Br}, \mathrm{Ca}, \mathrm{Cl}, \mathrm{Cu}, \mathrm{Fe}, \mathrm{I}, \mathrm{K}, \mathrm{Li}, \mathrm{Mg}, \mathrm{Mn}, \mathrm{Na}, \mathrm{P}, \mathrm{S}, \mathrm{Si}, \mathrm{Sr}, \mathrm{V}$, and $\mathrm{Zn}$ ) mass fractions. Future studies should be directed toward using other analytical methods which will extend the list of ChE investigated in normal and adenomatous thyroid. Secondly, the sample size of TA group was relatively small. It was not allow us to carry out the investigations of ChE contents in TA group using differentials like gender, histological and functional types of adenoma, stage of disease, and dietary habits of healthy persons and patients with TA. Lastly, generalization of our results may be limited to Russian population. Despite these limitations, this study provides evidence on adenoma-specific tissue $\mathrm{Al}, \mathrm{B}, \mathrm{Br}, \mathrm{Cl}, \mathrm{Cu}, \mathrm{I}, \mathrm{Na}$, and Zn level alteration and shows the necessity to continue ChE research of adenomatous thyroid.

\section{Conclusion}

In this work, ChE measurements were carried out in the tissue samples of normal thyroid and TA using the combination of non-destructive INAA-SLR and destructive ICP-AES methods. It was shown that the combination of these methods is an adequate analytical tool for the determination of $\mathrm{Al}, \mathrm{B}, \mathrm{Ba}, \mathrm{Br}, \mathrm{Ca}, \mathrm{Cl}, \mathrm{Cu}, \mathrm{Fe}, \mathrm{I}, \mathrm{K}, \mathrm{Li}, \mathrm{Mg}, \mathrm{Mn}, \mathrm{Na}, \mathrm{P}, \mathrm{S}, \mathrm{Si}, \mathrm{Sr}, \mathrm{V}$, and $\mathrm{Zn}$ content in the tissue samples of human thyroid, including needle-biopsy cores. It was observed that in adenomatous tissues content of $\mathrm{Al}, \mathrm{B}, \mathrm{Br}, \mathrm{Cl}, \mathrm{Cu}, \mathrm{Na}$, and $\mathrm{Zn}$ significantly increased whereas the level of I decreased in a comparison with the normal thyroid tissues. In our opinion, the increase in levels of $\mathrm{Al}, \mathrm{B}, \mathrm{Br}, \mathrm{Cl}, \mathrm{Cu}, \mathrm{Na}$, and $\mathrm{Zn}$, as well as the decrease in level of $\mathrm{I}$ in adenomatous tissue might demonstrate an involvement of these ChE in etiology and pathogenesis of TA. It was supposed that the changes in levels $\mathrm{Al}, \mathrm{B}, \mathrm{Br}, \mathrm{Cl}, \mathrm{Cu}, \mathrm{I}, \mathrm{Na}$, and $\mathrm{Zn}$ in thyroid tissue can be used as TA markers.

\section{Compliance with ethical standards}

\section{Acknowledgments}

The author is extremely grateful to Profs. B.M. Vtyurin and V.S. Medvedev, Medical Radiological Research Center, Obninsk, as well as to Dr. Yu. Choporov, Head of the Forensic Medicine Department of City Hospital, Obninsk, for supplying thyroid samples. The author is also grateful to Dr. Karandaschev V, Dr. Nosenko S, and Moskvina I, Institute of Microelectronics Technology and High Purity Materials, Chernogolovka, Russia, for their help in ICP-AES analysis. 


\section{Disclosure of conflict of interest}

The author declares that he has no competing interests.

\section{Statement of ethical approval}

All studies were approved by the Ethical Committees of the Medical Radiological Research Centre (MRRC), Obninsk. All the procedures performed in studies involving human participants were in accordance with the ethical standards of the institutional and/or national research committee and with the 1964 Helsinki declaration and its later amendments, or with comparable ethical standards.

\section{Statement of informed consent}

Informed consent was obtained from all individual participants included in the study.

\section{References}

[1] Carlé A, Krejbjerg A, Laurberg P. Epidemiology of nodular goitre. Influence of iodine intake. Best Pract Res Clin Endocrinol Metab. 2014; 28(4): 465-79.

[2] Kant R, Davis A, Verma V. Thyroid nodules: Advances in evaluation and management. Am Fam Physician. 2020; 102(5): 298-304.

[3] Hoang VT, Trinh CT. A Review of the Pathology, Diagnosis and Management of Colloid Goitre. Eur Endocrinol. 2020; 16(2): 131-5.

[4] Derwahl M, Studer H. Multinodular goitre: 'much more to it than simply iodine deficiency'. Baillieres Best Pract Res Clin Endocrinol Metab. 2000; 14(4): 577-600.

[5] Zaichick V. Iodine excess and thyroid cancer. J Trace Elements in Experimental Medidicne. 1998; 11(4): 508-9.

[6] Zaichick V, Iljina T. Dietary iodine supplementation effect on the rat thyroid 131I blastomogenic action. In: Die Bedentung der Mengen- und Spurenelemente. 18. Arbeitstangung. Jena: Friedrich-Schiller-Universitat. 1998; 294-306.

[7] Kim S, Kwon YS, Kim JY, Hong KH, Park YK. Association between Iodine Nutrition Status and Thyroid DiseaseRelated Hormone in Korean Adults: Korean National Health and Nutrition Examination Survey VI (2013-2015). Nutrients 2019; 11(11): 27-57.

[8] Vargas-Uricoechea P, Pinzón-Fernández MV, Bastidas-Sánchez BE, Jojoa-Tobar E, Ramírez-Bejarano LE, MurilloPalacios J. Iodine Status in the Colombian Population and the Impact of Universal Salt Iodization: A Double-Edged Sword? J Nutr Metab. 2019; 6239243.

[9] Stojsavljević A, Rovčanin B, Krstić D, Jagodić J, Borković-Mitić S, Paunović I, Živaljević V, Mitić B, GavrovićJankulović M, Manojlović D. Cadmium as main endocrine disruptor in papillary thyroid carcinoma and the significance of Cd/Se ratio for thyroid tissue pathophysiology. J Trace Elem Med Biol. 2019; 55: 190-5.

[10] Fahim YA, Sharaf NE, Hasani IW, Ragab EA, Abdelhakim HK. Assessment of Thyroid Function and Oxidative Stress State in Foundry Workers Exposed to Lead. J Health Pollut. 2020; 10(27): 200903.

[11] Liu M, Song J, Jiang Y, Lin Y, Peng J, Liang H, Wang C, Jiang J, Liu X, Wei W, Peng J, Liu S, Li Y, Xu N, Zhou D, Zhang Q, Zhang J. A case-control study on the association of mineral elements exposure and thyroid tumor and goiter. Ecotoxicol Environ Saf. 2021; 208: 111615.

[12] Zaichick V. Medical elementology as a new scientific discipline. J Radioanal Nucl Chem. 2006; 269: 303-9.

[13] Moncayo R, Moncayo H. A post-publication analysis of the idealized upper reference value of $2.5 \mathrm{mIU} / \mathrm{L}$ for TSH: Time to support the thyroid axis with magnesium and iron especially in the setting of reproduction medicine. BBA Clin. 2017; 7: 115-9.

[14] Beyersmann D, Hartwig A. Carcinogenic metal compounds: recent insight into molecular and cellular mechanisms. Arch Toxicol. 2008; 82(8): 493-512.

[15] Martinez-Zamudio R, Ha HC. Environmental epigenetics in metal exposure. Epigenetics. 2011; 6(7): 820-7.

[16] Zaĭchik VE, Raibukhin YuS, Melnik AD, Cherkashin VI. Neutron-activation analysis in the study of the behavior of iodine in the organism. Med Radiol (Mosk). 1970; 15(1): 33-6. 
[17] Zaĭchik VE, Matveenko EG, Vtiurin BM, Medvedev VS. Intrathyroid iodine in the diagnosis of thyroid cancer. Vopr Onkol. 1982; 28(3): 18-24.

[18] Zaichick V, Tsyb AF, Vtyurin BM. Trace elements and thyroid cancer. Analyst. 1995; 120(3): 817-21.

[19] Zaichick VYe, Choporov YuYa. Determination of the natural level of human intra-thyroid iodine by instrumental neutron activation analysis. J Radioanal Nucl Chem. 1996; 207(1): 153-61.

[20] Zaichick V. In vivo and in vitro application of energy-dispersive XRF in clinical investigations: experience and the future. J Trace Elements in Experimental Medidicne. 1998; 11(4): 509-10.

[21] Zaichick V, Zaichick S. Energy-dispersive X-ray fluorescence of iodine in thyroid puncture biopsy specimens. J Trace Microprobe Tech. 1999; 17(2): 219-32.

[22] Zaichick V. Relevance of, and potentiality for in vivo intrathyroidal iodine determination. Ann N Y Acad Sci. 2000; 904: 630-2.

[23] Zaichick V, Zaichick S. Normal human intrathyroidal iodine. Sci Total Environ. 1997; 206(1): 39-56.

[24] Zaichick V. Human intrathyroidal iodine in health and non-thyroidal disease. In: New aspects of trace element research (Eds: M.Abdulla, M.Bost, S.Gamon, P.Arnaud, G.Chazot). London: Smith-Gordon; and Tokyo: Nishimura. 1999; 114-9.

[25] Zaichick V, Zaichick S. Age-related changes of some trace element contents in intact thyroid of females investigated by energy dispersive X-ray fluorescent analysis. Trends Geriatr Healthc. 2017; 1(1): 31-8.

[26] Zaichick V, Zaichick S. Age-related changes of some trace element contents in intact thyroid of males investigated by energy dispersive X-ray fluorescent analysis. MOJ Gerontol Ger. 2017; 1(5): 00028.

[27] Zaichick V, Zaichick S. Age-related changes of $\mathrm{Br}, \mathrm{Ca}, \mathrm{Cl}, \mathrm{I}, \mathrm{K}, \mathrm{Mg}, \mathrm{Mn}$, and Na contents in intact thyroid of females investigated by neutron activation analysis. Curr Updates Aging. 2017; 1: 5.1.

[28] Zaichick V, Zaichick S. Age-related changes of $\mathrm{Br}, \mathrm{Ca}, \mathrm{Cl}, \mathrm{I}, \mathrm{K}, \mathrm{Mg}, \mathrm{Mn}$, and Na contents in intact thyroid of males investigated by neutron activation analysis. J Aging Age Relat Dis. 2017; 1(1): 1002.

[29] Zaichick V, Zaichick S. Age-related changes of Ag, Co, Cr, Fe, Hg, Rb, Sb, Sc, Se, and Zn contents in intact thyroid of females investigated by neutron activation analysis. J Gerontol Geriatr Med. 2017; 3: 015.

[30] Zaichick V, Zaichick S. Age-related changes of Ag, Co, Cr, Fe, Hg, Rb, Sb, Sc, Se, and Zn contents in intact thyroid of males investigated by neutron activation analysis. Curr Trends Biomedical Eng Biosci. 2017; 4(4): 555644.

[31] Zaichick V, Zaichick S. Effect of age on chemical element contents in female thyroid investigated by some nuclear analytical methods. MicroMedicine. 2018; 6(1): 47-61.

[32] Zaichick V, Zaichick S. Neutron activation and X-ray fluorescent analysis in study of association between age and chemical element contents in thyroid of males. Op Acc J Bio Eng Bio Sci. 2018; 2(4): 202-12.

[33] Zaichick V, Zaichick S. Variation with age of chemical element contents in females' thyroids investigated by neutron activation analysis and inductively coupled plasma atomic emission spectrometry. J Biochem Analyt Stud. 2018; 3(1): 1-10.

[34] Zaichick V, Zaichick S. Association between Age and Twenty Chemical Element Contents in Intact Thyroid of Males. SM Gerontol Geriatr Res. 2018; 2(1): 10-14.

[35] Zaichick V, Zaichick S. Associations between age and 50 trace element contents and relationships in intact thyroid of males. Aging Clin Exp Res. 2018; 30(9): 1059-70.

[36] Zaichick V, Zaichick S. Possible role of inadequate quantities of intra-thyroidal bromine, rubidium and zinc in the etiology of female subclinical hypothyroidism. EC Gynaecology. 2018; 7(3): 107-15.

[37] Zaichick V, Zaichick S. Possible role of inadequate quantities of intra-thyroidal bromine, calcium and magnesium in the etiology of female subclinical hypothyroidism. Int Gyn and Women's Health. 2018; 1(3): IGWHC.MS.ID.000113.

[38] Zaichick V, Zaichick S. Possible role of inadequate quantities of intra-thyroidal cobalt, rubidium and zinc in the etiology of female subclinical hypothyroidism. Womens Health Sci J. 2018; 2(1): 000108.

[39] Zaichick V, Zaichick S. Association between female subclinical hypothyroidism and inadequate quantities of some intra-thyroidal chemical elements investigated by X-ray fluorescence and neutron activation analysis. Gynaecology and Perinatology. 2018; 2(4): 340-55. 
[40] Zaichick V, Zaichick S. Investigation of association between the high risk of female subclinical hypothyroidism and inadequate quantities of twenty intra-thyroidal chemical elements. Clin Res: Gynecol Obstet 2018; 1(1): 118.

[41] Zaichick V, Zaichick S. Investigation of association between the high risk of female subclinical hypothyroidism and inadequate quantities of intra-thyroidal trace elements using neutron activation and inductively coupled plasma mass spectrometry. Acta Scientific Medical Sciences. 2018; 2(9): 23-37.

[42] Zaichick V, Zaichick S. Trace element contents in thyroid cancer investigated by energy dispersive X-ray fluorescent analysis. American Journal of Cancer Research and Reviews. 2018; 2: 5.

[43] Zaichick V, Zaichick S. Trace element contents in thyroid cancer investigated by instrumental neutron activation analysis. J Oncol Res. 2018; 2(1): 1-13.

[44] Zaichick V, Zaichick S. Variation in selected chemical element contents associated with malignant tumors of human thyroid gland. Cancer Studies. 2018; 2(1): 2.

[45] Zaichick V, Zaichick S. Twenty chemical element contents in normal and cancerous thyroid. Int J Hematol Blo Dis. 2018; 3(2): 1-13.

[46] Zaichick V, Zaichick S. Levels of chemical element contents in thyroid as potential biomarkers for cancer diagnosis (a preliminary study). J Cancer Metastasis Treat. 2018; 4: 60.

[47] Zaichick V, Zaichick S. Fifty trace element contents in normal and cancerous thyroid. Acta Scientific Cancer Biology. 2018; 2(8): 21-38.

[48] Zaichick V, Zaichick S. Instrumental effect on the contamination of biomedical samples in the course of sampling. The Journal of Analytical Chemistry. 1996; 51(12): 1200-5.

[49] Zaichick V, Zaichick S. A search for losses of chemical elements during freeze-drying of biological materials. J Radioanal Nucl Chem 1997; 218(2): 249-53.

[50] Zaichick S, Zaichick V. The effect of age and gender on 37 chemical element contents in scalp hair of healthy humans. Biol Trace Elem Res. 2010; 134(1): 41-54.

[51] Zaichick V, Nosenko S, Moskvina I. The effect of age on 12 chemical element contents in intact prostate of adult men investigated by inductively coupled plasma atomic emission spectrometry. Biol Trace Elem Res. 2012; 147: 49-58.

[52] Zaichick V, Zaichick S. NAA-SLR and ICP-AES Application in the assessment of mass fraction of 19 chemical elements in pediatric and young adult prostate glands. Biol Trace Elem Res. 2013; 156: 357-66.

[53] Zaichick V, Zaichick S. Determination of trace elements in adults and geriatric prostate combining neutron activation with inductively coupled plasma atomic emission spectrometry. Open Journal of Biochemistry. 2014; 1(2): 16-33.

[54] Zaichick S, Zaichick V. INAA application in the age dynamics assessment of $\mathrm{Br}, \mathrm{Ca}, \mathrm{Cl}, \mathrm{K}, \mathrm{Mg}$, $\mathrm{Mn}$, and $\mathrm{Na}$ content in the normal human prostate. J Radioanal Nucl Chem. 2011; 288: 197-202.

[55] Zaichick V, Zaichick S. The effect of age on $\mathrm{Br}, \mathrm{Ca}, \mathrm{Cl}, \mathrm{K}, \mathrm{Mg}$, Mn, and $\mathrm{Na}$ mass fraction in pediatric and young adult prostate glands investigated by neutron activation analysis. J Appl Radiat Isot. 2013; 82: 145-51.

[56] Zaichick V. Applications of synthetic reference materials in the Medical Radiological Research Centre. Fresenius J Anal Chem. 1995; 352: 219-23.

[57] Korelo AM, Zaichick V. Software to optimize the multielement INAA of medical and environmental samples. In: Activation Analysis in Environment Protection. Dubna, Russia: Joint Institute for Nuclear Research. 1993; 32632 .

[58] Kortev AI, Dontsov GI, Lyascheva AP. Bioelements and a human pathology. Sverdlovsk, Russia: Middle-Ural publishing-house.1972.

[59] Kamenev VF. About trace element contents in thyroid of adults. In: Trace Elements in Agriculture and Medicine. Ulan-Ude, Russia: Buryatia publishing-house. 1963; 12-6.

[60] Tipton IH, Cook MJ. Trace elements in human tissue. Part II. Adult subjects from the United States. Health Phys. 1963; 9(2): 103-45. 
[61] Reitblat MA, Kropachyev AM. Some trace elements in thyroid of the Perm Pricam'ya residents. Proceedings of Perm Medical Institute. 1967; 78: 157-64.

[62] Forssen A. Inorganic elements in the human body. Ann Med Exp Biol Fenn. 1972; 50(3): 99-162.

[63] Zhu H, Wang N, Zhang Y, Wu Q, Chen R, Gao J, Chang P, Liu Q, Fan T, Li J, Wang J, Wang J. Element contents in organs and tissues of Chinese adult men. Health Phys. 2010; 98(1): 61-73.

[64] Salimi J, Moosavi K, Vatankhah S, Yaghoobi A. Investigation of heavy trace elements in neoplastic and nonneoplastic human thyroid tissue: A study by proton-induced X-ray emissions. Iran J Radiat Res. 2004; 1(4): 2116.

[65] Boulyga SF, Zhuk IV, Lomonosova EM, Kanash NV, Bazhanova NN. Determination of microelements in thyroids of the inhabitants of Belarus by neutron activation analysis using the k0-method. J Radioanal Nucl Chem. 1997; 222(1-2): 11-4.

[66] Reddy SB, Charles MJ, Kumar MR, Reddy BS, Anjaneyulu Ch, Raju GJN, Sundareswar B, Vijayan V. Trace elemental analysis of adenoma and carcinoma thyroid by PIXE method. Nucl Instrum Methods Phys Res B: Beam Interactions with Materials and Atoms. 2002; 196(3-4): 333-9.

[67] Woodard HQ, White DR. The composition of body tissues. Brit J Radiol. 1986; 708: 1209-18.

[68] Ataullachanov IA. Age-related changes of manganese, cobalt, coper, zinc, and iron contents in the endocrine glands of females. Probl Endocrinol. 1969; 15(2): 98-102.

[69] Neimark II, Timoschnikov VM. Development of carcinoma of the thyroid gland in person residing in the focus of goiter endemic. Probl Endocrinil. 1978; 24(3): 28-32.

[70] Zabala J, Carrion N, Murillo M, Quintana M, Chirinos J, Seijas N, Duarte L, Brätter P. Determination of normal human intrathyroidal iodine in Caracas population. J Trace Elem Med Biol. 2009; 23(1): 9-14.

[71] Zakutinsky DI, Parfyenov YuD, Selivanova LN. Data book on the radioactive isotopes toxicology. Moscow: State Publishing House of Medical Literature. 1962.

[72] Remiz AM. Endemic goiter and trace elements in Kabardino-Balkaria ASSR. In: The 5th meeting of chirurgeons of Northern Caucasia. Rostov-on-Don. 1962; 276-8.

[73] Li AA. Level of some macro- and trace element contents in blood and thyroid of patients with endemic goiter in Kalinin region. PhD thesis. Kalinin, Russia: Kalinin medical institute. 1973.

[74] Boulyga SF, Becker JS, Malenchenko AF, Dietze H-J. Application of ICP-MS for multielement analysis in small sample amounts of pathological thyroid tissue. Microchim Acta. 2000; 134(3-4): 215-22.

[75] Soman SD, Joseph KT, Raut SJ, Mulay CD, Parameshwaran M, Panday VK. Studies of major and trace element content in human tissues. Health Phys. 1970; 19(5): 641-56.

[76] Novikiv GV, Vlasova ZA. Some organism functions in connection with the iodine content in diet and feed of experimental animals. In: Role of Trace Elements in Agriculture and Medicine. Leningrad: Nauka. 1970; 2: 6-7.

[77] Bredikhin LM, Soroka VP. Trace element metabolism in patients with thyroid goiter under treatment. Vrach Delo. 1969; 51(6): 81-4.

[78] Byrne AR. Vanadium in foods and in human body fluids and tissues. Sci Total Environ. 1978; 10: 17-30.

[79] Maeda K, Yokode Y, Sasa Y, Kusuyama H, Uda M. Multielemental analysis of human thyroid glands using particle induced X-ray emission (PIXE). Nucl Instrum Methods Phys Res B. 1987; 22(1-3): 188-90.

[80] Turetskaia ES. Studies on goitrous thyroid glands for iodine and bromine content. Probl Endokrinol Gormonoter. 1961; 7(2): 75-80.

[81] Stojsavljević A, Rovčanin B, Krstić D, Borković-Mitić S, Paunović I, Kodranov I, Gavrović-Jankulović M, Manojlović D. Evaluation of trace metals in thyroid tissues: Comparative analysis with benign and malignant thyroid diseases. Ecotoxicol Environ Saf. 2019; 183: 109479.

[82] Tadros TG, Maisey MN, Ng Tang Fui SC, Turner P. The iodine concentration in benign and malignant thyroid nodules measured by X-ray fluorescence. Br J Radiol. 1981; 54(643): 626-9.

[83] Koch HJ, Smith ER. The determination of copper and zinc in normal and pathologic thyroid tissue. J Clin Endocrinol. 1956; 16(1): 123-9. 
[84] Zagrodzki P, Nicol F, Arthur JR, Słowiaczek M, Walas S, Mrowiec H, Wietecha-Posłuszny R. Selenoenzymes, laboratory parameters, and trace elements in different types of thyroid tumor. Biol Trace Elem Res. 2010; 134(1): 25-40.

[85] Katoh Y, Sato T, Yamamoto Y. Determination of multielement concentrations in normal human organs from the Japanese. Biol Trace Elem Res. 2002; 90(1-3): 57-70.

[86] Schroeder HA, Tipton IH, Nason AP. Trace metals in man: strontium and barium. J Chron Dis. 1972; 25(9): 491517.

[87] Zaichick V. Sampling, sample storage and preparation of biomaterials for INAA in clinical medicine, occupational and environmental health. In: Harmonization of Health-Related Environmental Measurements Using Nuclear and Isotopic Techniques. Vienna: IAEA. 1997; 123-33.

[88] Zaichick V. Losses of chemical elements in biological samples under the dry aching process. Trace Elements in Medicine. 2004; 5(3): 17-22.

[89] Krewski D, Yokel RA, Nieboer E, Borchelt D, Cohen J, Harry J, Kacew S, Lindsay J, Mahfouz AM, Rondeau V. Human health risk assessment for aluminium, aluminium oxide, and aluminium hydroxide. J Toxicol Environ Health Part B. 2007; 10: 1-269.

[90] Naghii MR, Mofid M, Asgari AR, Hedayati M, Daneshpour MS. Comparative effects of daily and weekly boron supplementation on plasma steroid hormones and proinflammatory cytokines. J Trace Elem Med Biol. 2011; 25: 54-8.

[91] Pizzorno L. Nothing boring about boron. Integr Med (Encinitas). 2015; 14: 35-48.

[92] Pavelka S. Radiometric determination of thyrotoxic effects of some xenobiotics. Rad Applic. 2016; 1(2): 155-8.

[93] Maschkovsky MD. The sedatives. In: The Medicaments. 15th ed. Moscow: Novaya Volna. 2005; 72-86.

[94] Zaichick V. X-ray fluorescence analysis of bromine for the estimation of extracellular water. J Appl Radiat Isot.1998; 49(12): 1165-9.

[95] Lyshchik A, Moses R, Barnes SI, Higashi T, Asato R, Miga MI, Gore JC, Fleischer AC. Quantitative analysis of tumor vascularity in benign and malignant solid thyroid nodules J Ultrasound Med. 2007; 26(6): 837-46.

[96] Li Y, Trush MA. DNA damage resulting from the oxidation of hydroquinone by copper: role for a $\mathrm{Cu}(\mathrm{II}) / \mathrm{Cu}(\mathrm{I})$ redox cycle and reactive oxygen generation. Carcinogenesis. 1993; 14(7): 1303-11.

[97] Trump BF, Berezesky IK, Phelps PC. Sodium and calcium regulation and the role of the cytoskeleton in the pathogenesis of disease: a review and hypothesis. Scan Electron Microsc. 1981; (Pt 2): 434-54.

[98] Ravera S, Reyna-Neyra A, Ferrandino G, Amzel M, Carrasco N. The sodium/iodide symporter (NIS): Molecular physiology and preclinical and clinical applications. Annu Rev Physiol. 2017; 79: 261-89.

[99] Bozym RA, Chimienti F, Giblin LJ, Gross GW, Korichneva I, Li Y, Libert S, Maret W, Parviz M, Frederickson CJ, Thompson RB. Free zinc ions outside a narrow concentration range are toxic to a variety of cells in vitro. Exp Biol Med (Maywood). 2010; 235(6): 741-50.

[100] Matusik RJ, Kreis C, McNicol P, Sweetland R, Mullin C, Fleming WH, Dodd JG. Regulation of prostatic genes: role of androgens and zinc in gene expression. Biochem Cell Biol. 1986; 64: 601-7.

[101] Blok LJ, Grossmann ME, Perry JE, Tindall DJ. Characterization of an early growth response gene, which encodes a zinc finger transcription factor, potentially involved in cell cycle regulation. Mol Endocrinol. 1995; 9(11): 161020.

[102] Zezerov YeG. Hormonal and molecular-biological factors of prostate cancer pathogenesis. Voprosy Oncologii. 2001; 47(2): 174-81.

[103] Truong-Tran AQ, Ho LH, Chai F, Zalewski PD. Cellular zinc fluxes and the regulation of apoptosis/gene-directed cell death. J Nutr. 2000; 130(5S Suppl): 1459S-66S.

[104] Kontargiris E, Vadalouka A, Ragos V, Kalfakakou V. Zinc inhibits apoptosis and maintains NEP downregulation, induced by Ropivacaine, in HaCaT cells. Biol Trace Elem Res. 2012; 150: 460-6.

[105] Liang D, Yang M, Guo B, Cao J, Yang L, Guo X, Li Y, Gao Z. Zinc inhibits H2O2-induced MC3T3-E1 cells apoptosis via MAPK and PI3K/AKT pathways. Biol Trace Elem Res. 2012; 148: 420-9. 
World Journal of Advanced Research and Reviews, 2021, 11(03), 242-257

[106] Zhang X, Liang D, Guo B, Yang L, Wang L, Ma J. Zinc inhibits high glucose-induced apoptosis in peritoneal mesothelial cells. Biol Trace Elem Res. 2012; 150: 424-32. 